Journal of Social Sciences 6 (3): 416-423, 2010

ISSN 1549-3652

(C) 2010 Science Publications

\title{
How Does Human Capital Affect on Growth in Different Economies?
}

\author{
Mehdi Safdari, Mohammad Shahiki and Zahra Sheidaee \\ Department of Economics, Sistan and Baluchestan University, Zahedan, Iran
}

\begin{abstract}
Problem statement: The main objective of this study was to investigate how human capital can affect growth in different economies. Approach: For this purpose, we investigated the model, which the growth rate of total factor productivity depends on human capital stock level using a cross-country panel approach for 104 countries in five-year intervals during the 1980-2005. Results: The finding of this study showed that human capital through its effect on the speed of technology adoption from abroad has positive effect and significantly on growth in total samples of countries while human capital directly in developed countries enter negatively inverse developing countries. Conclusion: Moreover human capital affects growth in different ways it has more effects on per capital growth through technology/catch-up component than domestic innovation component. Moreover human capital of different ways has different effects on growth but in total it has positive effect on economic growth.
\end{abstract}

Key words: Human capital, growth, panel approach

\section{INTRODUCTION}

The importance of human capital in economic growth has been emphasized by many theoretical models of economic growth, such as Nelson and Phelps (1966); Lucas (1988); Rebelo (1991) and Mulligan and Sala-I-Martin (1997) and also many empirical studies of growth for a broad cross-section of countries such as Romer (1990a); Barro (1991); Kyriacou (1991) and Benhabib and Spiegel (1992) have used proxies for human capital.

Although empirical researches have established the positive influence of human capital to economic growth, but many studies cast doubt on the traditional role given to human capital, merely as a factor of production and there is disagreement about the mechanisms through which this happens. Romer (1990a) suggests that human capital may directly affect on productivity by enhancing the capacity of countries to create new technologies. Aghion and Howitt (1997, chapter 10) distinguish two major frameworks within the endogenous growth literature, i.e., the Lucas approach and the Nelson-Phelps approach. The former, based on Lucas (1988) and shared by neo-classical growth theory, assumes that growth is driven by the accumulation of human capital. It treats human capital like an ordinary input in the production function. In particular, differences in growth rates across countries are assumed to be primarily due to differences in the rates of human capital accumulation. The second approach, based on Nelson and Phelps (1966), relates growth to the stock of human capital which affects a country's ability to innovate and catch-up with more advanced countries (Aghion and Howitt, 1997).

Benhabib and Spiegel (1994), with adopting from Nelson and Phelps (1966) framework, introduce an alternative model. Their model allows human capital to influence growth through two channels: First, human capital levels directly influence the rate of domestically produced technological innovation (Romer, 1990a). Second, the human capital stock affects the speed of adoption of technology from abroad (Nelson and Phelps, 1966). In their model, at any time, there exists some country which is the world leader in technology. The speed, on which nations catch up to this leader country, is then a function of their human capital stocks (Benhabib and Spiegel, 1994). They make a very good attempt in this direction, by introducing a cross-country approach during a twenty-year interval of 1965-1985. Their empirical findings show that human capital stock in levels plays a role in determining the growth of per capital income whether negatively or insignificantly. They also obtain positive results that human capital could be effective in economic growth as an engine of attracting physical capital and as a determinant of the magnitude of a country's Solow residual.

This study extends the study of Benhabib and Spiegel (1994) in several important ways, while Benhabib's research was based on a cross-country data using ordinary least square for 78 countries in a twentyyear interval of 1965-1985, this study utilizes a panel data for 104 countries in five-year intervals of 1980- 


\section{J. Social Sci., 6 (3): 416-423, 2010}

2005, we also have used a greater sample for estimation including 25 developed countries (OECD) and 79 developing countries instead of third of poorest and richest countries. We also use average years of schooling of updated data set by Barro and Lee (2010) data as a proxy for human capital instead of Kyriacou human capital measure.

Then we compared the effect of human capital stock in economic growth in developing countries with developed countries. We also estimated the physical stock by perpetual inventory method, following Bernanke and Gurkaynak (2001) approach. The rest of the study is outlined as follows: At first provides a brief of information description about related literature are presented. In continue, describes the data and methodology, in addition discussion and empirical results. The study finishes with a conclusion.

Literature review: The importance of human capital in economic growth has been emphasized by many researchers. In fact, after failure of the Solow model in explaining income difference across countries, many approaches have been implemented to augment the standard of Solow growth model. More evidences gradually suggested the importance of human capital in economic growth. Kendrick (1976) estimated that over half of the total US capital stock in 1969 was human capital. Azariadis and Drazen (1990) found that without a highly literate labor force, no country was able to experience fast growth during the postwar period.

The next question is how human capital affects economic growth. Nelson and Phelps (1966) suggested that the ability of a country to import and use new technologies from abroad is also a function of the country`s human capital stock. Romer (1990a) suggested that human capital might directly affect productivity by enhancing the capacity of a country to create new technologies. Lucas (1990) said that physical capital failed to flow to poor countries because of their relatively poor endowments of complementary human capital. Kyriacou (1991) examined the role of human capital in explaining the inability of some developing countries to catch-up with more advanced countries, using a cross-country Cobb-Douglas production for large number of countries during 19701985 periods. He found that coefficient of human capital (years of schooling in the labor force) is negative and insignificant (Kyriacou, 1991).

Mankiw et al. (1992) examined whether the Solow growth model was consistent with the international variation in the standard of living or not. It showed that an augmented Solow model that included accumulation of human capital as well as physical capital provided an excellent description of the cross-country data and found that the human capital variable as an ordinary input in the production function entered significantly in explaining income differences (Mankiw et al., 1992). Islam (1995) extended Mankiw et al. (1992) study by introducing a panel data approach. He selected the same country sets and analyzed the data in the period 19601985. He found a better evidence of convergence in a panel data scenario, but failed in showing the significance of human capital in the method (Islam, 1995). Benhabib and Spiegel (1994) adapted the Nelson and Phelps (1966) framework to analyze the effect of human capital on the speed of technological catch-up and diffusion and examined how these changes influence the growth. The alternative model indicated a more positive role of human capital in determining per capita income (Benhabib and Spiegel, 1994). Deepak et al. (2003) empirically analyzed the determinants of income-level convergence. Specifically, the effect of human capital on per capita income was estimated for 22 countries of OECD over the 1955-1990 periods using pooled data. Human capital was modeled as a latent variable and results indicated that it was a significant factor in explaining the variation of per capita income levels among the OECD countries (Deepak et al., 2003).

\section{MATERIALS AND METHODS}

The theoretical framework: With the emergence of the endogenous growth theories in 1980s, the relationship between economic policy and growth became a highly debated issue. In the theoretical literature, discussions are focused on different channels through which economic policy affects economic growth. The endogenous growth theory is a reaction to the traditional Neo-classical growth models, represented by (Solow, 1956; Levine and Renelt, 1992; Levine, 1997; Easterly and Levine, 2001).

In fact the main distinction between old and new growth theories is that the former utilizes the assumption that returns to the capital stock is diminishing, while the latter argues that returns to capital itself or, in a wider sense, to the stock of physical and human capital formation is constant or increasing (Sala-I-Martin, 1990). This then implies that those variables that lead to non-decreasing returns drive the growth rate. Many candidates have been recommended as the source of non-decreasing returns: particularly, the stock of human capital Lucas (1988); accumulated capital, Rebelo (1991); research and development, Romer (1986; 1990a); or public infrastructure investment (Barro, 1991). Thus, endogenous growth models highlight sectors of the 
economy that influence the growth path of an economy. This can be simply shown in a Cobb-Douglas production function in which per capita income, $\mathrm{Y}_{t}$, is dependent upon three input factors, Labor, $\mathrm{L}_{\mathrm{t}}$, physical capital, $\mathrm{K}_{\mathrm{t}}$ and human capital, $\mathrm{H}_{\mathrm{t}}$.

Assuming a Cobb-Douglas technology, $\mathrm{Y}_{\mathrm{t}}=\mathrm{A}_{\mathrm{t}}\left(\mathrm{H}_{\mathrm{t}}\right)$ $\mathrm{K}_{\mathrm{t}}^{\alpha} \mathrm{L}_{\mathrm{t}}^{\mathrm{B}} \varepsilon_{\mathrm{t}}$ and taking $\log$ differences, the relationship for long-term growth can be expressed as (Benhabib and Spiegel, 1994):

$$
\begin{aligned}
\left(\log \mathrm{Y}_{\mathrm{T}}-\log \mathrm{Y}_{0}\right)= & {\left[\log \mathrm{A}_{\mathrm{T}}\left(\mathrm{H}_{\mathrm{t}}\right)-\log \mathrm{A}_{0}\left(\mathrm{H}_{\mathrm{t}}\right)\right] } \\
& +\alpha\left(\log \mathrm{K}_{\mathrm{T}}-\log \mathrm{K}_{0}\right) \\
& +\beta\left(\log \mathrm{L}_{\mathrm{T}}-\log \mathrm{L}_{0}\right) \\
& +\left(\log \varepsilon_{\mathrm{T}}-\log \varepsilon_{0}\right)
\end{aligned}
$$

According to two models (their first model state that time lag between the creation of a new technique and its adoption is a decreasing function of some index of average educational attainment, $\mathrm{h}$. w, denote the lag, thus: $\mathrm{A}(\mathrm{t})=\mathrm{T}(\mathrm{t}-\mathrm{w}(\mathrm{h}))$, $\left.\mathrm{w}^{\prime}(\mathrm{h})<0\right)$ of technological diffusion presented by Nelson and Phelps (1966). Their second model states that the rate at which the latest, theoretical technology is realized in improved technological practice depends upon educational attainment and upon the gap between the theoretical level of technology (is defined as the best-practice level of technology that would prevail if technological diffusion were completely instantaneous and advances exogenously at a constant exponential rate $\lambda$ : $\mathrm{T}(\mathrm{t})=\mathrm{T}_{0} \mathrm{e}^{\lambda \mathrm{t}}$, $\lambda>0$ ) and the level of technology in practice (The level of technology in practice equals the theoretical level of technology w years ago, w a decreasing function of h):

$A(t)=c(h)[T(t)-A(t)]$

Equivalently:

$$
\frac{\dot{\mathrm{A}}}{\mathrm{A}}=\mathrm{c}(\mathrm{H})\left[\frac{\mathrm{T}(\mathrm{t})-\mathrm{A}(\mathrm{t})}{\mathrm{A}(\mathrm{t})}\right] \dot{\mathrm{c}}(\mathrm{h})>0 \mathrm{c}(0)=0
$$

Thus the rate of increase of the technology in practice (not the level) is an increasing function of education attainment and proportional to the gap, (T (t)A (t))/A (t) (Nelson and Phelps, 1966).

In other hand many theories (for example Lucas 1988) emphasizing the endogenous model of growth and technical progress have modeled the growth of A, directly as a function of the educational level Romer (1990b) has also argued that the level of human capital may have an influence on growth of $\mathrm{A}$, both directly and through its effect on the speed of the catching-up process (Benhabib and Spiegel, 1994).
Benhabib and Spiegel (1994) with adoption this two hypothesis introduce an alternative model that human capital to influence the technological progress through two channels: By directly affecting the ability of countries to innovate new technologies (Romer, 1990a) and by technological catch-up and diffusion between countries (Nelson and Phelps, 1966).

Thus, for a country $i$, the growth of total factor productivity, depending on two factors. The first is the level of human capital, reflecting the effect of domestic endogenous innovation. The second is an interactive term that involves the level of human capital and the technological lag of a country behind the leader (Country with the highest initial technology level, A (0)), to catch-up effects as following:

$$
\begin{aligned}
& {\left[\log A_{T}\left(H_{t}\right)-\log A_{0}\left(H_{t}\right)\right]_{i}=} \\
& c+g H_{i}+m_{i}\left[\left(Y_{\text {max }}-Y_{i}\right) / Y_{i}\right]
\end{aligned}
$$

where, c represents exogenous technological progress, $\mathrm{gH}_{\mathrm{i}}$ indicates endogenous technological progress associate with the ability of a country to innovate new technologies domestically, which is a function of human capital and $\mathrm{mH}_{\mathrm{i}}\left[\left(\mathrm{Y}_{\max }-\mathrm{Y}_{\mathrm{i}}\right) / \mathrm{Y}_{\mathrm{i}}\right]\left(\mathrm{Y}_{\max }\right.$ is the initial income per worker for the leading country, that Luxembourg had highest $Y_{i}$ in 1980) 0 represents the diffusion of technology from abroad, which is also a function of human capital. The term "domestic innovation" shows that human capital stocks enhance technological progress independently, while the term "catch-up" indicates that with keeping human capital levels constant, countries with low level of productivity will experience faster rates of growth of technology (Benhabib and Spiegel, 1994).

Equation 4 can be written:

$$
\begin{aligned}
& {\left[\log \mathrm{A}_{\mathrm{T}}\left(\mathrm{H}_{\mathrm{t}}\right)-\log \mathrm{A}_{0}\left(\mathrm{H}_{\mathrm{t}}\right)\right]_{\mathrm{i}}=} \\
& \mathrm{c}+(\mathrm{g}-\mathrm{m}) \mathrm{H}_{\mathrm{i}}+\mathrm{mH}_{\mathrm{i}}\left(\mathrm{Y}_{\max } / \mathrm{Y}_{\mathrm{i}}\right) \\
& \left(\log \mathrm{Y}_{\mathrm{T}}-\log \mathrm{Y}_{0}\right)=\mathrm{c}+(\mathrm{g}-\mathrm{m}) \mathrm{H}_{\mathrm{i}}+\mathrm{mH}_{\mathrm{i}}\left(\mathrm{Y}_{\max } / \mathrm{Y}_{\mathrm{i}}\right) \\
& +\alpha\left(\log \mathrm{K}_{\mathrm{T}}-\log \mathrm{K}_{0}\right)+\beta\left(\log \mathrm{L}_{\mathrm{T}}-\log \mathrm{L}_{0}\right) \\
& +\left(\log \varepsilon_{\mathrm{T}}-\log \varepsilon_{0}\right)
\end{aligned}
$$

This equation is used to test that how human capital impacts on productivity growth.

Summary statistics: The research period is determined by the data availability. The five-year interval data is employed for some economies including developing economies and developed economies during the 19802005. The per capita GDP in constant prices and 
income per worker derived from Penn World Table (PWT version 6.3) and labor force is available from the World Bank data. The Average of the schooling years in total population over age 15 is constructed by Barro and Lee (2010) and is used in this study as human capital proxy. We construct the physical capital stock series by the perpetual inventory method (the Perpetual inventory method: $\mathrm{K}_{\mathrm{t}}=\mathrm{K}_{0}(1-\mathrm{S})^{\mathrm{t}}+\Sigma \mathrm{I}_{\mathrm{i}}(1-\mathrm{S})^{\mathrm{t}-1} \mathrm{i}=1, \ldots$, t-1) following Bernanke and Gurkaynak (2001) approach Based on Bernanke and Gurkaynak (2001) approach, an initial value of the capital stock series for each country, $\mathrm{i}$ is generated by: $\mathrm{K}_{0}=\mathrm{I}_{1} /\left(\mathrm{g}_{1}+\delta\right)$ where $\mathrm{K}_{0}$ is the capital stock, $\mathrm{I}_{1}$ is the capital flow at year 1 or the year after the initial year, $\mathrm{g}_{1}$ is the 5-year average annual growth rate around year 1 and $\delta$ is the depreciation which is assumed to be the same countries (0.06). The data on investment-to-GDP ratio, real GDP growth are from the Penn World Table (PWT version $6.3)$.

\section{RESULTS}

Unit-root tests: Recent literature in econometrics suggests that before undertaking an empirical analysis, unit root tests should be investigated for data series, because regression analysis carried out with nonstationary variables may invalidate many of the assumptions of regression analysis. If a time series has a unit root, a widespread and convenient way to remove non-stationary would be by taking first differences of the relevant variable. A non-stationary series, which transfers to a non stationary one by difference d times, is called an integration of order d and denoted as I (d) (Charemza and Deadman, 1997). Five types of panel unit root tests in Eviews are computable as following: Levin et al. (2002); Breitung (2000) and Im et al. (2003), Fisher-type tests using ADF and PP tests (Maddala and Wu (1999) and Hadri (2000). The results of the some unit root tests for the variables are presented in Table 1.
Cointegration tests: In next step, the tests of cointegration in a panel setting have been focused in recent literature. The purpose of the cointegration test is to determine whether a group of non-stationary series is cointegrated or not. If such stationary linear combination exists, it may be interpreted as a long-run equilibrium relationship among the variables.

Pedroni (1999) and Kao (1999) and Fisher-type test using an underlying Johansen methodology (Maddala and Wu (1999) are types of panel co integration tests.

The results of Kao (1999) cointegration test are presented in the Table 2.

The results indicate that cointegration or long-run equilibrium relationship exists between variables.

According to the previous economic discussions, we estimated equation 6 , using the cross-country panel approach in three groups of countries.

The results are presented in Table 3 .

As was expected, coefficients for physical capital accumulation and labor force enter in all models positively and significantly.

The obtained results of model 1 that were investigated on 104 country-samples showed that human capital accumulation affected productivity growth positively, however human capital, through technology adoption from abroad is more effective on growth than domestic technology.

In fact Coefficient for human capital in levels had positive effect and insignificantly on per capita growth.

The results of model 2, with the samples, containing 79 developing countries, were almost similar to the results found for the full sample. While Catch-up component entered positively and significantly, domestic innovation was positive but insignificant.

In model 3 we investigated the samples, including 25 developed countries; the results showed that although catch-up component had positive effect and significant, domestic innovation appeared with negative sign.

Table 1: Unit root test results

\begin{tabular}{|c|c|c|c|c|c|c|c|c|}
\hline \multirow[b]{2}{*}{ Variable } & \multicolumn{2}{|c|}{ Levin, Lin and Chu t* } & \multicolumn{2}{|c|}{ Im, Pesaran and Shin w-stat } & \multicolumn{2}{|c|}{ ADF-Fisher chi-square } & \multicolumn{2}{|c|}{ pp-fisher chi square } \\
\hline & $\mathrm{F}$ & $\mathrm{T}$ & $\mathrm{F}$ & $\mathrm{T}$ & $\mathrm{F}$ & $\mathrm{T}$ & $\mathrm{F}$ & $\mathrm{T}$ \\
\hline LRGDP & -3.737 & -49.968 & 4.909 & -1.502 & 121.025 & 241.735 & 159.383 & 412.825 \\
\hline $\mathrm{H}$ & $-11.894 *$ & $-11.628^{*}$ & 0.943 & 1.049 & 146.122 & 55.990 & $233.967 *$ & 106.45 \\
\hline $\mathrm{H}\left(\mathrm{Y}_{\max } / \mathrm{Y}\right)$ & 7.411 & $-20.710^{*}$ & 4.401 & -0.939 & 144.548 & 172.468 & 236.732 & $279.244 *$ \\
\hline LL & $-5.913 *$ & $-8.772 *$ & 3.994 & 3.134 & 187.277 & 113.900 & $384.317 *$ & 196.373 \\
\hline LK & $-6.563^{*}$ & $-56.492 *$ & 1.557 & -1.519 & $262.305^{*}$ & $261.413 *$ & $459.002 *$ & $471.980^{*}$ \\
\hline D (LRGDP) & $-43.357^{*}$ & $-522.890 *$ & $-14.350^{*}$ & $-43.134 *$ & $389.308^{*}$ & $351.545^{*}$ & $441.856^{*}$ & $496.533^{*}$ \\
\hline $\mathrm{D}(\mathrm{LL})$ & $-12.471^{*}$ & $-54.850 *$ & $-2.243 *$ & $-9.266^{*}$ & 222.318 & $283.131 *$ & $262.310^{*}$ & $425.097^{*}$ \\
\hline D (LK) & $-53.093^{*}$ & $-22.435^{*}$ & $-11.157 *$ & $-47.018 *$ & $358.518^{*}$ & $316.395^{*}$ & $432.432 *$ & $455.821^{*}$ \\
\hline
\end{tabular}

Note: $\mathrm{F}$ and $\mathrm{T}$ indicate the models that allow for an intercept and intercept and trend, respectively. Asterisk * shows significance at $1 \%$ level. Maximum lag is used as lag length 
Table 2: Kao (1999) cointegration tests results

\begin{tabular}{llllll}
\hline Null & & Rho & Prob. & t-statistic & Prob. \\
\hline No & DF & -7.617328 & 0.0000 & -12.44178 & 0.0000 \\
Cointegration & DF* $^{*}$ & -4.839625 & 0.0000 & -11.19954 & 0.0000 \\
\hline
\end{tabular}

Table 3: Panel estimation-depended variable: $\Delta \log Y^{\mathrm{a}} 1980-2005$

\begin{tabular}{lclll}
\hline Variable & Coefficient & Std. error & t-statistic & Prob model $1^{\mathrm{b}}$ \\
\hline $\mathrm{C}$ & -0.2010 & 0.0587 & -3.4381 & 0.0006 \\
$\mathrm{H}$ & 0.0084 & 0.0086 & 0.9798 & 0.3327 \\
$\mathrm{H}\left(\mathrm{Y}_{\max } / \mathrm{Y}\right)$ & 0.0022 & 0.0001 & 11.1857 & 0.0000 \\
$\Delta \operatorname{logL}$ & 0.5612 & 0.1225 & 5.5783 & 0.0000 \\
$\Delta \operatorname{logk}$ & 0.2051 & 0.0586 & 3.4998 & 0.0005 \\
$\mathrm{~F}$ & 4.3492 & & & \\
$\mathrm{R}^{2}$ & 0.5300 & & & \\
$\mathrm{M}^{\mathrm{M}}$ & -0.2449 & 0.0648 & -3.7758 & 0.0002 \\
$\mathrm{H}$ & 0.0096 & 0.0111 & 0.8632 & 0.3887 \\
$\mathrm{H}\left(\mathrm{Y}_{\max } / \mathrm{Y}\right)$ & 0.0022 & 0.0002 & 9.9323 & 0.0000 \\
$\Delta \operatorname{logL}$ & 0.5337 & 0.1434 & 3.7199 & 0.0002 \\
$\Delta \operatorname{logk}$ & 0.1992 & 0.0664 & 2.9969 & 0.0029 \\
$\mathrm{~F}$ & 4.1881 & & & \\
$\mathrm{R}^{2}$ & 0.5200 & & & \\
$\mathrm{M}$ odel $3^{\mathrm{d}}$ & & & & \\
$\mathrm{C}$ & 0.1332 & 0.0374 & 3.5590 & 0.0007 \\
$\mathrm{H}$ & -0.0321 & 0.0042 & -7.5783 & 0.0000 \\
$\mathrm{H}\left(\mathrm{Y}_{\max } / \mathrm{Y}\right)$ & 0.0115 & 0.0013 & 8.6087 & 0.0000 \\
$\Delta \operatorname{logL}$ & 0.6007 & 0.1400 & 4.2891 & 0.0001 \\
$\Delta \operatorname{logk}$ & 0.4188 & 0.0871 & 4.8046 & 0.0000 \\
$\mathrm{~F}$ & 10.7067 & & & \\
$\mathrm{R}^{2}$ & 0.8100 & & & \\
\hline
\end{tabular}

${ }^{a}: \Delta \log \mathrm{X}$, refers to the $\log$ difference of end and initial period in variable X. ${ }^{\text {b. }}$ : Including all countries in the sample. ${ }^{\text {c: }}$ Including 79 developing countries. ${ }^{\mathrm{d}}$ : Including 25 of OECD countries

\section{DISCUSSION}

Although there exists wide spread evidence that indicates human capital have positive effects on growth in the empirical literature, the findings in Table 4 show that it is not always and it depends on the path that human capital influence growth. So that human capital has positive effect and significant on growth through its effect on the speed of technology adoption from abroad in all countries, but directly and through domestic innovation only in developing countries enter positively.

In comparison to obtained results of Benhabib and Spiegel (1994) estimation, the results of our estimation are somewhat different. While in Benhabib, human capital in levels entered negatively in developing countries, in our estimation it enters as a positive, however insignificantly. It also entered positively and significantly in Benhabib estimation on three of richest countries, while the obtained results of model 3 on 25 OECD countries show domestic innovation appears with negative sign.

Table 4: Capital stock used in this study ${ }^{\text {a }}$

\begin{tabular}{|c|c|c|c|c|c|c|}
\hline \multirow[b]{2}{*}{ Country } & \multicolumn{6}{|c|}{ Advanced OECD (25) } \\
\hline & K1980 & K1985 & K1990 & K1995 & K2000 & K2005 \\
\hline Australia & $8 \mathrm{E}+11$ & $9.59 \mathrm{E}+11$ & $1.17 \mathrm{E}+12$ & $1.33 \mathrm{E}+12$ & $1.64 \mathrm{E}+12$ & $2.07 \mathrm{E}+12$ \\
\hline Austria & $2.63 \mathrm{E}+11$ & $3.22 \mathrm{E}+11$ & $3.81 \mathrm{E}+11$ & $4.55 \mathrm{E}+11$ & $5.32 \mathrm{E}+11$ & $6.01 \mathrm{E}+11$ \\
\hline Belgium & $2.96 \mathrm{E}+11$ & $3.45 \mathrm{E}+11$ & $4 \mathrm{E}+11$ & $4.83 \mathrm{E}+11$ & $5.71 \mathrm{E}+11$ & $6.57 \mathrm{E}+11$ \\
\hline Canada & $8.2 \mathrm{E}+11$ & $1.06 \mathrm{E}+12$ & $1.4 \mathrm{E}+12$ & $1.66 \mathrm{E}+12$ & $2 \mathrm{E}+12$ & $2.47 \mathrm{E}+12$ \\
\hline Denmark & $1.64 \mathrm{E}+12$ & $1.73 \mathrm{E}+12$ & $2.05 \mathrm{E}+12$ & $2.25 \mathrm{E}+12$ & $2.68 \mathrm{E}+12$ & $3.16 \mathrm{E}+12$ \\
\hline Finland & $1.65 \mathrm{E}+11$ & $2.08 \mathrm{E}+11$ & $2.25 \mathrm{E}+11$ & $2.68 \mathrm{E}+11$ & $2.88 \mathrm{E}+11$ & $3.28 \mathrm{E}+11$ \\
\hline France & $1.82 \mathrm{E}+12$ & $2.15 \mathrm{E}+12$ & $2.5 \mathrm{E}+12$ & $2.85 \mathrm{E}+12$ & $3.18 \mathrm{E}+12$ & $3.67 \mathrm{E}+12$ \\
\hline Germany & $2.89 \mathrm{E}+12$ & $3.25 \mathrm{E}+12$ & $3.67 \mathrm{E}+12$ & $4.34 \mathrm{E}+12$ & $4.9 \mathrm{E}+12$ & $5.23 \mathrm{E}+12$ \\
\hline Greece & $2.39 \mathrm{E}+11$ & $2.68 \mathrm{E}+11$ & $2.88 \mathrm{E}+11$ & $3.07 \mathrm{E}+11$ & $3.4 \mathrm{E}+11$ & $4.16 \mathrm{E}+11$ \\
\hline Hungary & $2.39 \mathrm{E}+13$ & $2.96 \mathrm{E}+13$ & $3.34 \mathrm{E}+13$ & $3.41 \mathrm{E}+13$ & $4.07 \mathrm{E}+13$ & $5.12 \mathrm{E}+13$ \\
\hline Iceland & $7.08 \mathrm{E}+11$ & $9.56 \mathrm{E}+11$ & $1.17 \mathrm{E} 12$ & $1.29 \mathrm{E}+12$ & $1.52 \mathrm{E}+12$ & $1.86 \mathrm{E}+12$ \\
\hline Ireland & $9.97 \mathrm{E}+10$ & $1.29 \mathrm{E}+11$ & $1.43 \mathrm{E}+11$ & $1.63 \mathrm{E}+11$ & $2.22 \mathrm{E}+11$ & $3.09 \mathrm{E}+11$ \\
\hline Italy & $1.55 \mathrm{E}+12$ & $1.84 \mathrm{E}+12$ & $2.18 \mathrm{E}+12$ & $2.52 \mathrm{E}+12$ & $2.87 \mathrm{E}+12$ & $3.31 \mathrm{E}+12$ \\
\hline Japan & $6.48 \mathrm{E}+14$ & $8.06 \mathrm{E}+14$ & $1.02 \mathrm{E}+15$ & $1.27 \mathrm{E}+15$ & $1.45 \mathrm{E}+15$ & $1.55 \mathrm{E}+15$ \\
\hline Korea, rep & $2.21 \mathrm{E}+14$ & $3.69 \mathrm{E}+14$ & $6.33 \mathrm{E}+14$ & $1.14 \mathrm{E}+15$ & $1.67 \mathrm{E}+15$ & $2.15 \mathrm{E}+15$ \\
\hline Luxembourg & $1.77 \mathrm{E}+10$ & $2.02 \mathrm{E}+10$ & $2.52 \mathrm{E}+10$ & $3.3 \mathrm{E}+10$ & $4.18 \mathrm{E}+10$ & $5.46 \mathrm{E}+10$ \\
\hline Netherland & $5.68 \mathrm{E}+11$ & $6.26 \mathrm{E}+11$ & $7.15 \mathrm{E}+11$ & $8.18 \mathrm{E}+11$ & $9.71 \mathrm{E}+11$ & $1.12 \mathrm{E}+12$ \\
\hline New Zealand & $1.44 \mathrm{E}+11$ & $1.72 \mathrm{E}+11$ & $2.02 \mathrm{E}+11$ & $2.23 \mathrm{E}+11$ & $2.68 \mathrm{E}+11$ & $3.3 \mathrm{E}+11$ \\
\hline Norway & $1.83 \mathrm{E}+12$ & $2.3 \mathrm{E}+12$ & $2.78 \mathrm{E}+12$ & $2.96 \mathrm{E}+12$ & $3.47 \mathrm{E}+12$ & $3.92 \mathrm{E}+12$ \\
\hline Portugal & $1.23 \mathrm{E}+11$ & $1.55 \mathrm{E}+11$ & $1.84 \mathrm{E}+11$ & $2.33 \mathrm{E}+11$ & $3.03 \mathrm{E}+11$ & $3.74 \mathrm{E}+11$ \\
\hline Spain & $8.36 \mathrm{E}+11$ & $9.83 \mathrm{E}+11$ & $1.21 \mathrm{E}+12$ & $1.5 \mathrm{E}+12$ & $1.81 \mathrm{E}+12$ & $2.29 \mathrm{E}+12$ \\
\hline Sweden & $2.91 \mathrm{E}+12$ & $3.24 \mathrm{E}+12$ & $3.81 \mathrm{E}+12$ & $4.15 \mathrm{E}+12$ & $4.54 \mathrm{E}+12$ & $5.09 \mathrm{E}+12$ \\
\hline Switzerland & $1.12 \mathrm{E}+12$ & $1.1 \mathrm{E}+12$ & $1.16 \mathrm{E}+12$ & $1.22 \mathrm{E}+12$ & $1.29 \mathrm{E}+12$ & $1.34 \mathrm{E}+12$ \\
\hline United Kingdom & $9.25 \mathrm{E}+11$ & $1.04 \mathrm{E}+12$ & $1.26 \mathrm{E}+12$ & $1.44 \mathrm{E}+12$ & $1.71 \mathrm{E}+12$ & $2.07 \mathrm{E}+12$ \\
\hline United state & $7.54 \mathrm{E}+12$ & $9.36 \mathrm{E}+12$ & $1.17 \mathrm{E}+13$ & $1.38 \mathrm{E}+13$ & $1.78 \mathrm{E}+13$ & $2.21 \mathrm{E}+13$ \\
\hline \multicolumn{7}{|l|}{ Developing (79) } \\
\hline Albania & $1.71 \mathrm{E}+12$ & $2.17 \mathrm{E}+12$ & $2.53 \mathrm{E}+12$ & $2.26 \mathrm{E}+12$ & $2.14 \mathrm{E}+12$ & $2.45 \mathrm{E}+12$ \\
\hline Algeria & $1.44 \mathrm{E}+13$ & $1.89 \mathrm{E}+13$ & $2.15 \mathrm{E}+13$ & $2.19 \mathrm{E}+13$ & $2.2 \mathrm{E}+13$ & $2.38 \mathrm{E}+13$ \\
\hline Argentina & $8.79 E+11$ & $9.41 \mathrm{E}+11$ & $9.31 \mathrm{E}+11$ & $9.92 \mathrm{E}+11$ & $1.17 \mathrm{E}+12$ & $1.19 \mathrm{E}+12$ \\
\hline Bangladesh & $2.06 \mathrm{E}+12$ & $3 E+12$ & $4.21 \mathrm{E}+12$ & $5.62 \mathrm{E}+12$ & $7.96 \mathrm{E}+12$ & $1.15 \mathrm{E}+13$ \\
\hline Belize & $1.85 \mathrm{E}+09$ & $2.01 \mathrm{E}+09$ & $2.32 \mathrm{E}+09$ & $3.01 \mathrm{E}+09$ & $3.56 \mathrm{E}+09$ & $4.61 \mathrm{E}+09$ \\
\hline Benin & $2.42 \mathrm{E}+12$ & $2.81 \mathrm{E}+12$ & $2.95 \mathrm{E}+12$ & $3.13 \mathrm{E}+12$ & $3.61 \mathrm{E}+12$ & $4.43 \mathrm{E}+12$ \\
\hline Bolivia & $6.96 \mathrm{E}+10$ & $7.5 E+10$ & $8.17 \mathrm{E}+10$ & $8.95 \mathrm{E}+10$ & $1.14 \mathrm{E}+11$ & $1.26 \mathrm{E}+11$ \\
\hline Botswana & $1.22 \mathrm{E}+10$ & $2.02 \mathrm{E}+10$ & $2.81 \mathrm{E}+10$ & $4.92 \mathrm{E}+10$ & $6.99 \mathrm{E}+10$ & $9.21 \mathrm{E}+10$ \\
\hline
\end{tabular}


J. Social Sci., 6 (3): 416-423, 2010

Table 4: Continued

\begin{tabular}{|c|c|c|c|c|c|c|}
\hline Brazil & $1.92 \mathrm{E}+12$ & $2.58 \mathrm{E}+12$ & $3.11 \mathrm{E}+12$ & $3.45 \mathrm{E}+12$ & $4.06 \mathrm{E}+12$ & $4.43 \mathrm{E}+12$ \\
\hline Bulgaria & $5.86 \mathrm{E}+10$ & $8.86 \mathrm{E}+10$ & $1.2 \mathrm{E}+11$ & $1.08 \mathrm{E}+11$ & $9.4 \mathrm{E}+10$ & $1 \mathrm{E}+11$ \\
\hline Burundi & $8.98 \mathrm{E}+11$ & $1.4 \mathrm{E}+12$ & $1.39 \mathrm{E}+12$ & $1.58 \mathrm{E}+12$ & $1.43 \mathrm{E}+12$ & $1.37 \mathrm{E}+12$ \\
\hline Cameroon & $6.74 \mathrm{E}+12$ & $1.13 \mathrm{E}+13$ & $1.54 \mathrm{E}+13$ & $1.56 \mathrm{E}+13$ & $1.58 \mathrm{E}+13$ & $1.8 \mathrm{E}+13$ \\
\hline Central Africa & $1.01 \mathrm{E}+12$ & $9.67 \mathrm{E}+11$ & $1.05 \mathrm{E}+12$ & $1.09 \mathrm{E}+12$ & $1.09 \mathrm{E}+12$ & $1.04 \mathrm{E}+12$ \\
\hline Chile & $2.45 \mathrm{E}+13$ & $3.03 \mathrm{E}+13$ & $3.56 \mathrm{E}+13$ & $5.04 \mathrm{E}+13$ & $7.82 \mathrm{E}+13$ & $1.02 \mathrm{E}+14$ \\
\hline Chile & $4.03 \mathrm{E}+12$ & $6.11 \mathrm{E}+12$ & $1.03 \mathrm{E}+13$ & $1.66 \mathrm{E}+13$ & $2.8 \mathrm{E}+13$ & $4.46 \mathrm{E}+13$ \\
\hline Colombia & $1.82 \mathrm{E}+14$ & $2.57 \mathrm{E}+14$ & $3.11 \mathrm{E}+14$ & $4 \mathrm{E}+14$ & $4.93 E+14$ & $5.3 \mathrm{E}+14$ \\
\hline Congo Dem rep & $4.71 \mathrm{E}+12$ & $5.41 \mathrm{E}+12$ & $5.92 \mathrm{E}+12$ & $6.34 \mathrm{E}+12$ & $5.75 E+12$ & $6.16 \mathrm{E}+12$ \\
\hline Congo rep & $2 \mathrm{E}+12$ & $4.56 \mathrm{E}+12$ & $4.76 \mathrm{E}+12$ & $5 \mathrm{E}+12$ & $5.45 \mathrm{E}+12$ & $5.83 \mathrm{E}+12$ \\
\hline Costa Rica & $5.4 \mathrm{E}+12$ & $6.52 \mathrm{E}+12$ & $8.35 \mathrm{E}+12$ & $1.07 \mathrm{E}+13$ & $1.34 \mathrm{E}+13$ & $1.76 \mathrm{E}+13$ \\
\hline Cote d'Ivoire & $1.02 \mathrm{E}+13$ & $1.15 \mathrm{E}+13$ & $1.06 \mathrm{E}+13$ & $1.03 \mathrm{E}+13$ & $1.15 \mathrm{E}+13$ & $1.17 \mathrm{E}+13$ \\
\hline Dominican rep & $4.39 \mathrm{E}+11$ & $5.92 \mathrm{E}+11$ & $7.63 \mathrm{E}+11$ & $9.4 \mathrm{E}+11$ & $1.34 \mathrm{E}+12$ & $1.75 \mathrm{E}+12$ \\
\hline Ecuador & $4.08 \mathrm{E}+10$ & $5.66 \mathrm{E}+10$ & $6.44 \mathrm{E}+10$ & $7.13 \mathrm{E}+10$ & $7.65 \mathrm{E}+10$ & $8.58 \mathrm{E}+10$ \\
\hline Egypt & $2.49 \mathrm{E}+11$ & $4.45 \mathrm{E}+11$ & $5.04 \mathrm{E}+11$ & $5.37 \mathrm{E}+11$ & $6.56 \mathrm{E}+11$ & $8.1 \mathrm{E}+11$ \\
\hline El Salvador & $1.33 \mathrm{E}+10$ & $1.42 \mathrm{E}+10$ & $1.55 \mathrm{E}+10$ & $1.83 \mathrm{E}+10$ & $2.29 \mathrm{E}+10$ & $2.76 \mathrm{E}+10$ \\
\hline Fiji & $5.09 \mathrm{E}+09$ & $6.81 \mathrm{E}+09$ & $6.99 \mathrm{E}+09$ & $8.91 \mathrm{E}+09$ & $1.05 \mathrm{E}+10$ & $1.14 \mathrm{E}+10$ \\
\hline Gabon & $6.43 \mathrm{E}+12$ & $8.34 \mathrm{E}+12$ & $9.29 \mathrm{E}+12$ & $9.68 \mathrm{E}+12$ & $1.09 \mathrm{E}+13$ & $1.14 \mathrm{E}+13$ \\
\hline Gambia & $5.19 \mathrm{E}+09$ & $6.46 E+09$ & $8.76 \mathrm{E}+09$ & $1.41 \mathrm{E}+10$ & $1.93 \mathrm{E}+10$ & $2.53 \mathrm{E}+10$ \\
\hline Ghana & $5.09 \mathrm{E}+10$ & $4.11 \mathrm{E}+10$ & $3.47 \mathrm{E}+10$ & $3.16 \mathrm{E}+10$ & $3.08 \mathrm{E}+10$ & $3.07 \mathrm{E}+10$ \\
\hline Guatemala & $1.54 \mathrm{E}+11$ & $1.86 \mathrm{E}+11$ & $2 \mathrm{E}+11$ & $2.41 \mathrm{E}+11$ & $2.94 \mathrm{E}+11$ & $3.79 \mathrm{E}+11$ \\
\hline Guyana & $7.86 \mathrm{E}+11$ & $8.68 \mathrm{E}+11$ & $8.18 \mathrm{E}+11$ & $9.2 \mathrm{E}+11$ & $1.02 \mathrm{E}+12$ & $1.01 \mathrm{E}+12$ \\
\hline Haiti & $1.22 \mathrm{E}+11$ & $1.76 \mathrm{E}+11$ & $2.2 \mathrm{E}+11$ & $2.18 \mathrm{E}+11$ & $2.36 \mathrm{E}+11$ & $2.59 \mathrm{E}+11$ \\
\hline Honduras & $1.33 \mathrm{E}+11$ & $1.6 \mathrm{E}+11$ & $1.91 \mathrm{E}+11$ & $2.68 \mathrm{E}+11$ & $3.69 \mathrm{E}+11$ & $4.54 \mathrm{E}+11$ \\
\hline India & $1.91 \mathrm{E}+13$ & $2.33 \mathrm{E}+13$ & $2.99 \mathrm{E}+13$ & $3.83 \mathrm{E}+13$ & $5.17 \mathrm{E}+13$ & $7.02 \mathrm{E}+13$ \\
\hline Indonesia & $1.26 \mathrm{E}+15$ & $2.36 \mathrm{E}+15$ & $3.61 \mathrm{E}+15$ & $5.28 \mathrm{E}+15$ & $6.97 \mathrm{E}+15$ & $7.44 \mathrm{E}+15$ \\
\hline Iran & $2.44 \mathrm{E}+15$ & $2.91 \mathrm{E}+15$ & $3.11 \mathrm{E}+15$ & $3.71 \mathrm{E}+15$ & 4. $23 \mathrm{E}+15$ & $5.05 \mathrm{E}+15$ \\
\hline Jamaica & $1.82 \mathrm{E}+12$ & $1.68 \mathrm{E}+12$ & $1.66 \mathrm{E}+12$ & $1.87 \mathrm{E}+12$ & $2.01 \mathrm{E}+12$ & $2.2 \mathrm{E}+12$ \\
\hline Jordan & $6.96 \mathrm{E}+09$ & $1.35 \mathrm{E}+10$ & $1.65 \mathrm{E}+10$ & $2.09 \mathrm{E}+10$ & $2.45 \mathrm{E}+10$ & $2.74 \mathrm{E}+10$ \\
\hline Kenya & $1.36 \mathrm{E}+12$ & $1.49 \mathrm{E}+12$ & $1.63 \mathrm{E}+12$ & $1.7 \mathrm{E}+12$ & $1.95 \mathrm{E}+12$ & $2.27 \mathrm{E}+12$ \\
\hline Lesotho & $7.19 \mathrm{E}+09$ & $1.04 \mathrm{E}+10$ & $1.42 \mathrm{E}+10$ & $2.47 \mathrm{E}+10$ & $3.4 \mathrm{E}+10$ & $3.92 \mathrm{E}+10$ \\
\hline Liberia & $2.23 \mathrm{E}+10$ & $1.77 \mathrm{E}+10$ & $1.36 \mathrm{E}+10$ & $1.01 \mathrm{E}+10$ & $1.57 \mathrm{E}+09$ & $5.74 \mathrm{E}+09$ \\
\hline Libya & $4.66 \mathrm{E}+10$ & $6.85 \mathrm{E}+10$ & $7.02 \mathrm{E}+10$ & $6.57 \mathrm{E}+10$ & $6.05 \mathrm{E}+10$ & $6.09 \mathrm{E}+10$ \\
\hline Malawi & $8.88 \mathrm{E}+11$ & $9.91 \mathrm{E}+11$ & $1 \mathrm{E}+12$ & $1.05 \mathrm{E}+12$ & $1.02 \mathrm{E}+12$ & $1.01 \mathrm{E}+12$ \\
\hline Malaysia & $1.3 \mathrm{E}+11$ & $2.56 \mathrm{E}+11$ & $3.38 \mathrm{E}+11$ & $5.77 \mathrm{E}+11$ & $8.9 \mathrm{E}+11$ & $1.08 \mathrm{E}+12$ \\
\hline Mali & $3.36 \mathrm{E}+12$ & $3.42 \mathrm{E}+12$ & $3.88 \mathrm{E}+12$ & $4.44 \mathrm{E}+12$ & $5.11 \mathrm{E}+12$ & $5.75 \mathrm{E}+12$ \\
\hline Mauritania & $7.79 \mathrm{E}+11$ & $9.72 \mathrm{E}+11$ & $9.8 \mathrm{E}+11$ & $8.81 \mathrm{E}+11$ & $8.77 \mathrm{E}+11$ & $1.16 \mathrm{E}+12$ \\
\hline Mauritius & $1.22 \mathrm{E}+11$ & $1.45 \mathrm{E}+11$ & $2 \mathrm{E}+11$ & $2.84 \mathrm{E}+11$ & $3.74 \mathrm{E}+11$ & $4.75 \mathrm{E}+11$ \\
\hline Mexico & $6.7 \mathrm{E}+12$ & $9.53 \mathrm{E}+12$ & $1.07 \mathrm{E}+13$ & $1.31 \mathrm{E}+13$ & $1.54 \mathrm{E}+13$ & $1.88 \mathrm{E}+13$ \\
\hline Morocco & $4.68 \mathrm{E}+11$ & $6.19 \mathrm{E}+11$ & $7.47 \mathrm{E}+11$ & $8.82 \mathrm{E}+11$ & $1.03 \mathrm{E}+12$ & $1.27 \mathrm{E}+12$ \\
\hline Mozambique & $7.77 \mathrm{E}+10$ & $8.95 \mathrm{E}+10$ & $1 \mathrm{E}+11$ & $1.21 \mathrm{E}+11$ & $1.72 \mathrm{E}+11$ & $2.36 \mathrm{E}+11$ \\
\hline Namibia & $6.95 E+10$ & $7.24 \mathrm{E}+10$ & $6.67 \mathrm{E}+10$ & $7.03 E+10$ & $7.71 E+10$ & $9.36 \mathrm{E}+10$ \\
\hline Nepal & $2.56 \mathrm{E}+11$ & $3.55 \mathrm{E}+11$ & $4.98 \mathrm{E}+11$ & $6.81 \mathrm{E}+11$ & $9.56 \mathrm{E}+11$ & $1.27 \mathrm{E}+12$ \\
\hline Nicaragua & $1.65 \mathrm{E}+11$ & $2.03 \mathrm{E}+11$ & $2.21 \mathrm{E}+11$ & $2.11 \mathrm{E}+11$ & $2.45 \mathrm{E}+11$ & $2.72 \mathrm{E}+11$ \\
\hline Niger & $1.66 \mathrm{E}+12$ & $2.03 E+12$ & $2.53 \mathrm{E}+12$ & $2.57 \mathrm{E}+12$ & $2.69 \mathrm{E}+12$ & $2.99 \mathrm{E}+12$ \\
\hline Pakistan & $4.84 \mathrm{E}+12$ & $6.49 \mathrm{E}+12$ & $8.54 \mathrm{E}+12$ & $1.1 \mathrm{E}+13$ & $1.31 \mathrm{E}+13$ & $1.51 \mathrm{E}+13$ \\
\hline Panama & $1.12 \mathrm{E}+10$ & $1.34 \mathrm{E}+10$ & $1.3 \mathrm{E}+10$ & $1.68 \mathrm{E}+10$ & $2.45 \mathrm{E}+10$ & $2.84 \mathrm{E}+10$ \\
\hline Papua New Guinea & $1.79 \mathrm{E}+10$ & $2.02 \mathrm{E}+10$ & $2.09 \mathrm{E}+10$ & $2.18 \mathrm{E}+10$ & $2.44 \mathrm{E}+10$ & $2.9 \mathrm{E}+10$ \\
\hline Paraguay & $3.85 \mathrm{E}+13$ & $6.73 E+13$ & $8.74 \mathrm{E}+13$ & $1.13 \mathrm{E}+14$ & $1.32 \mathrm{E}+14$ & $1.34 \mathrm{E}+14$ \\
\hline Peru & $2.12 \mathrm{E}+11$ & $2.87 \mathrm{E}+11$ & $3.16 \mathrm{E}+11$ & $3.5 \mathrm{E}+11$ & $4.49 \mathrm{E}+11$ & $4.99 \mathrm{E}+11$ \\
\hline Philippine & $3.59 \mathrm{E}+12$ & $5.16 \mathrm{E}+12$ & $5.53 \mathrm{E}+12$ & $6.6 \mathrm{E}+12$ & $8.01 E+12$ & $9.37 \mathrm{E}+12$ \\
\hline Romania & $5.38 \mathrm{E}+11$ & $8.35 E+11$ & $1.03 \mathrm{E}+12$ & $1 \mathrm{E}+12$ & $9.05 E+11$ & $8.82 \mathrm{E}+11$ \\
\hline Rwanda & $5.25 \mathrm{E}+11$ & $9.27 \mathrm{E}+11$ & $1.36 \mathrm{E}+12$ & $1.4 \mathrm{E}+12$ & $1.42 \mathrm{E}+12$ & $1.7 \mathrm{E}+12$ \\
\hline Senegal & $5.05 \mathrm{E}+12$ & $4.36 \mathrm{E}+12$ & $4.53 \mathrm{E}+12$ & $4.66 \mathrm{E}+12$ & $5.73 \mathrm{E}+12$ & $7.86 \mathrm{E}+12$ \\
\hline Sierra Leone & $6.17 \mathrm{E}+12$ & $6.52 \mathrm{E}+12$ & $6.71 \mathrm{E}+12$ & $6.64 \mathrm{E}+12$ & $5.56 \mathrm{E}+12$ & $4.07 \mathrm{E}+12$ \\
\hline Singapore & $7.22 \mathrm{E}+10$ & $1.3 \mathrm{E}+11$ & $1.75 E+11$ & $2.49 \mathrm{E}+11$ & $3.63 \mathrm{E}+11$ & $4.32 \mathrm{E}+11$ \\
\hline Sought Africa & $1.69 \mathrm{E}+12$ & $2.07 \mathrm{E}+12$ & $2.12 \mathrm{E}+12$ & $2.15 \mathrm{E}+12$ & $2.37 \mathrm{E}+12$ & $2.68 \mathrm{E}+12$ \\
\hline Sri Lanka & $2.49 \mathrm{E}+12$ & $3.08 \mathrm{E}+12$ & $3.45 \mathrm{E}+12$ & $3.89 \mathrm{E}+12$ & $4.58 \mathrm{E}+12$ & $5.43 \mathrm{E}+12$ \\
\hline Sudan & $1.95 \mathrm{E}+10$ & $2.33 E+10$ & $2.39 \mathrm{E}+10$ & $2.49 \mathrm{E}+10$ & $3.2 \mathrm{E}+10$ & $7.16 \mathrm{E}+10$ \\
\hline Swaziland & $8.89 \mathrm{E}+09$ & $1.38 \mathrm{E}+10$ & $1.76 \mathrm{E}+10$ & $2.34 \mathrm{E}+10$ & $2.85 \mathrm{E}+10$ & $3.41 \mathrm{E}+10$ \\
\hline Syrian Arab rep & $5.3 \mathrm{E}+11$ & $9.17 \mathrm{E}+11$ & $1.08 \mathrm{E}+12$ & $1.24 \mathrm{E}+12$ & $1.47 \mathrm{E}+12$ & $1.78 \mathrm{E}+12$ \\
\hline Thailand & $4.19 \mathrm{E}+12$ & $6.04 \mathrm{E}+12$ & $8.64 \mathrm{E}+12$ & $1.54 \mathrm{E}+13$ & $2 \mathrm{E}+13$ & $2.16 \mathrm{E}+13$ \\
\hline Togo & $2.83 \mathrm{E}+12$ & $3.21 \mathrm{E}+12$ & $3.25 \mathrm{E}+12$ & $3.06 \mathrm{E}+12$ & $3 E+12$ & $2.98 \mathrm{E}+12$ \\
\hline Trinidad and Tobago & $1.01 \mathrm{E}+11$ & $1.54 \mathrm{E}+11$ & $1.51 \mathrm{E}+11$ & $1.44 \mathrm{E}+11$ & $1.55 \mathrm{E}+11$ & $1.69 \mathrm{E}+11$ \\
\hline Tunisia & $4.02 \mathrm{E}+10$ & $5.96 \mathrm{E}+10$ & $6.52 \mathrm{E}+10$ & $7.38 \mathrm{E}+10$ & $8.42 \mathrm{E}+10$ & $9.98 \mathrm{E}+10$ \\
\hline Turkey & $2.19 \mathrm{E}+11$ & $2.68 \mathrm{E}+11$ & $3.68 \mathrm{E}+11$ & $5.2 \mathrm{E}+11$ & $7.07 \mathrm{E}+11$ & $8.64 \mathrm{E}+11$ \\
\hline Uganda & $1.98 \mathrm{E}+13$ & $1.69 \mathrm{E}+13$ & $1.63 \mathrm{E}+13$ & $1.7 \mathrm{E}+13$ & $2.1 \mathrm{E}+13$ & $2.65 E+13$ \\
\hline Uruguay & $3.88 \mathrm{E}+11$ & $4.77 \mathrm{E}+11$ & $4.7 \mathrm{E}+11$ & $5.29 \mathrm{E}+11$ & $6.54 \mathrm{E}+11$ & $6.67 \mathrm{E}+11$ \\
\hline Venezuela & $6.06 \mathrm{E}+14$ & $6.44 \mathrm{E}+14$ & $6.54 \mathrm{E}+14$ & $6.64 \mathrm{E}+14$ & $7.1 \mathrm{E}+14$ & $7.26 \mathrm{E}+14$ \\
\hline Zambia & $5.36 \mathrm{E}+13$ & $4.81 \mathrm{E}+13$ & $4.29 \mathrm{E}+13$ & $3.72 \mathrm{E}+13$ & $3.48 \mathrm{E}+13$ & $4.32 \mathrm{E}+13$ \\
\hline Zimbabwe & $2.89 \mathrm{E}+10$ & $3.59 \mathrm{E}+10$ & $4.27 \mathrm{E}+10$ & $5.51 \mathrm{E}+10$ & $6.41 \mathrm{E}+10$ & $6.33 \mathrm{E}+10$ \\
\hline
\end{tabular}

${ }^{\mathrm{a}} \mathrm{K}$ represent physical capital estimated by perpetual inventory method under 0.06 depreciation 


\section{CONCLUSION}

Human capital has been considered as an important factor in economic growth for a long time and empirical evidences for a broad group of countries confirm this linkage, but there are differences on how they impact human capital on economic growth. This study studied how the impact of human capital on per capital growth applies the introduced model by Benhabib and Spiegel (1994). We used cross-country panel data for 104 countries in five year-intervals from 1980-2005. In this model human capital affects on growth in two ways. First, human capital levels directly influence the rate of domestically produced technological innovation (Romer, 1990a). Second, the human capital stock affects on the speed of adoption of technology from abroad (Nelson and Phelps, 1966).

The obtained results are somewhat different from presented results by Benhabib at least for OECD countries, by emphasizing on the technology diffusion/catch-up component over the domestic innovation component.

The results showed that however, human capital had negative effect on growth in OECD countries in levels directly; it affected the growth positively and significantly by its influence on the speed of adoption technology from abroad. Considering the results, much of the effects of human capital on growth are through catch-up component. In developing countries, however, human capital had positive effect on growth through domestic innovation component, but it was insignificant. Such physical capital stock and labor force entered positively and significantly in growth equation.

\section{REFERENCES}

Aghion, P. and P. Howitt, 1997. Endogenous Growth Theory. 1st Edn., The MIT Press, Cambridge, Massachutets, ISBN: 10: 0262011662, pp: 710.

Azariadis, C. and A. Drazen, 1990. Threshold externalities in economic development. Q. J. Econ., 105: 501-526.

http://ideas.repec.org/a/tpr/qjecon/v105y1990i2p50 1-26.html

Barro, R.J., 1991. Economic growth in a cross section of countries. Q. J. Econ., 106: 407-443. http://ideas.repec.org/a/tpr/qjecon/v106y1991i2p40 7-43.html

Barro, R.J. and J.W. Lee, 2010. A New data set of educational attainment in the world, 1950-2010. NBER. http://www.nber.org/papers/w15902.pdf

Benhabib, J. and M.M. Spiegel, 1992. The role of human capital and political instability in economic development. IDEAS.

http://ideas.repec.org/p/cvs/starer/92-24.html
Benhabib, J. and M.M. Speigel, 1994. The role of human capital in economic development evidence from aggregate cross-country data. J. Monetary Econ., 34: 143-173. DOI: 10.1016/03043932(94)90047-7

Bernanke, B.S. and R.S. Gurkaynak, 2001. Is growth exogenous? Taking Mankiw, Romer and Weil seriously. NBER. http://www.nber.org/papers/w8365

Breitung, J., 2000. The Local Power of Some Unit Root Tests for Panel Data. In: Nonstationary Panels, Panel Cointegration and Dynamic Panels, Advances in Econometrics, Baltagi, B.H. (Ed.). JAI Press, Amsterdam, ISBN: 10: 0762306882, pp: 161-178.

Charemza, W.W. and D.F. Deadman, 1997. New Directions in Economic Practice: General to Specific Modeling, Cointegration and Vector Autoregression. 2nd Edn., Edward Elgar Publishers, Cheltenhaum, UK., ISBN: 10: 1858986036, pp: 360.

Deepak, S.D., J.L. Seal Jr. and C.B. Moss, 2003. Per capita income, human capital and inequality convergence: A latent-variable approach. J. Agric. Applied Econ., 35: 171-180.

Easterly, W. and R. Levine, 2001. It's not factor accumulation: Stylized facts and growth models. World Bank Econ. Rev., 15: 177-219.

Hadri, K., 2000. Testing for stationary in heterogenous panel data. J. Econ., 3: 148-161. http://ideas.repec.org/a/ect/emjrnl/v3y2000i2p148161.html

Im, K.S., M.H. Pesaran and Y. Shin, 2003. Testing for unit roots in heterogeneous panels. J. Econ., 115: 53-74. http://ideas.repec.org/a/eee/econom/v115y2003i1p 53-74.html

Islam, N., 1995. Growth empirics: A panel data approach. Q. J. Econ., 110: 1127-1170. http://www.jstor.org/pss/2946651

Kao, C., 1999. Spurios regression and residual-based tests for cointegration in panel data. J. Econ., 90: 1-44. http://www.citeulike.org/user/apwheele/article/427 3228

Kendrick, J.W., 1976. The Formation and Stocks of Total Capital. 1st Edn., National Bureau of Economic Research, United States, ISBN: 10: 0870142712, pp: 256.

Kyriacou, G.A., 1991. Level and growth effects of human capital: A cross-country study of the convergence hypothesis. IDEAS. http://ideas.repec.org/p/cvs/starer/91-26.html 
Levine, R., 1997. Financial development and economic growth: Views and agenda. J. Econ. Literat., 35: 688-726.

http://ideas.repec.org/a/aea/jeclit/v35y1997i2p688726.html

Levine, R. and D. Renelt, 1992. A sensitivity analysis of cross-country growth regressions. Am. Econ. Rev., $\quad$ 82: 942-963. http://www.jstor.org/pss/2117352

Levin, A., C.F. Lin and C.S.J. Chu, 2002. Unit root tests in panel data: Asymptotic and finite-sample properties. J. Econ., 108: 1-24. DOI: 10.1016/S0304-4076(01)00098-7

Lucas, Jr., R.E., 1988. On the mechanics of economic development. J. Monetary Econ., 22: 3-42. http://ideas.repec.org/a/eee/moneco/v22y1988i1p342.html

Lucas, Jr., R.E., 1990. Why doesn't capital flow from rich to poor countries? Am. Econ. Rev., 80: 92-96. http://ideas.repec.org/a/aea/aecrev/v80y1990i2p9296.html

Maddala, G.S. and S. Wu, 1999. A comparative study of unit root tests with panel data and a new simple test. Oxf. Bull. Econ. Stat., 61: 631-52. http://ideas.repec.org/a/bla/obuest/v61y1999i0p631 $-52 . h t m l$

Mankiw, N.G., D. Romer and D.N. Weil, 1992. A contribution to the empirics of economic growth. Q. J. $\quad$ Econ., 107: 407-437. http://ideas.repec.org/a/tpr/qjecon/v107y1992i2p40 7-37.html

Mulligan, C.B. and X. Sala-I-Martin, 1997. A labor income-based measure of the value of human capital. An application to the states of the United States. Jap. World Econ., 9: 159-191. DOI: 10.1016/S0922-1425(96)00236-8
Nelson, R.R. and E.S. Phelps, 1966. Investment in humans, technological diffusion and economic growth. Am. Econ. Rev., 56: 69-75. http://www.jstor.org/pss/1821269

Pedroni, P., 1999. Critical values for cointegration tests in heterogeneous panels with multiple regressors. Oxf. Bull. Econ. Stat., 61: 653-670. http://ideas.repec.org/a/bla/obuest/v61y1999i0p653 $-70 . \mathrm{html}$

Rebelo, S., 1991. Long run policy analysis and long-run growth. J. Politic. Econ., 99: 500-521. http://ideas.repec.org/a/ucp/jpolec/v99y1991i3p500 $-521 . h t m l$

Romer, P.M., 1986. Increasing returns and long-run growth. J. Politic. Econ., 94: 1002-1037. http://www.jstor.org/pss/1833190

Romer, P.M., 1990a. Endogenous technological change. J. Politic. Econ., 98: S71-102. http://ideas.repec.org/a/ucp/jpolec/v98y1990i5ps71 $-102 . h t m l$

Romer, P.M., 1990b. Human capital and growth: Theory and evidence. Carnegie Rochester Conf. Ser. Public Policy, 32: 251-286. http://ideas.repec.org/a/eee/crcspp/v32y1990ip251286.html

Sala-I Martin, X., 1990. Lecture notes on economic growth (I): Introduction to the literature and neoclassical models. NBER. http://www.nber.org/papers/w3563

Solow, R.M., 1956. A contribution to the theory of economic growth. Q. J. Econ., 70: 65-94. http://faculty.lebow.drexel.edu/LainczC/cal38/Gro wth/Solow_1956.pdf 